\title{
AL BORDE DEL MISTERIO: ACERCAMIENTO A LA POESÍA DE RAFAEL BALLESTEROS (1969-2010)
}

\author{
ON THE EDGE OF MISTERY: \\ AN APPROACH TO RAFAEL BALLESTEROS' POETRY (1969-2010)
}

Antonio Aguilar Sánchez

recataguilar@yahoo.es

Fecha de recepción: 09-12-2018

Fecha de aceptación: 23-01-2019

\section{RESUMEN}

El conjunto de la obra poética de Rafael Ballesteros, publicada a lo largo de las cuatro décadas que van de 1969 a 2010, no solo puede leerse como seguro puente entre las preocupaciones sociales de los 50 (gracias a la imbricación de la memoria personal en la memoria social) y la riqueza expresiva de los 70 (a través de la sabia manipulación de un lenguaje de ecos neovanguardistas), sino también como una apuesta vital, estética y reflexiva que sigue manteniendo su vigencia a través de la obra de algunos de los poetas más jóvenes y cercanos.

Palabras Clave: Poesía; Ballesteros; poesía social; neovanguardismo; poesía de los 70.

\section{Abstract}

The whole of Rafael Ballesteros' poetic work, published over four decades (19692010), cannot only be read as a bridge between the social concerns of the 1950s (thanks to the imbrication of his personal memory into his social one) and the expressive richness of the 1970 s, but also as a vital, aesthetic and reflexive commitment that is still valid and present through the work of some of the closest and youngest poets.

KEY WORDS: Poetry; Ballesteros; Social Poetry; New Avant-garde; 1970s poetry. 
Afirmaba José María Balcells ${ }^{1}$ en uno de los diversos artículos que el crítico ha dedicado a la obra de Rafael Ballesteros (Málaga, 1938) que en su personal poética reside

Una amalgama estética neorromántica, neovanguardista de cuño vallejiano, neosurrealista, y neobarroca [...] un universo en el que la mente y la palabra no cesan de pretender adentrarse en lo hondo, pero desestimando consagrarse a la indagación en lo que se presume oculto (Balcells, 2016: VIII)2.

Una certera conclusión que se acerca mucho al deseo expresado por el poeta Francisco Ruiz Noguera ${ }^{3}$ en los versos finales del poema "Rogativa", de La gruta y la luz, y que puede servir de emblema a esta aproximación crítica a la obra poética ballesteriana:

No te olvides de este ruego:

no nos dejes caer

- sin salvación posible-

en negra tentación de oscuridades,

pero mantennos — pido-

no lejos del misterio: siempre al borde (Ruiz Noguera, 2014).

Y quizás ese quedarse siempre al borde del misterio sea la imagen metafórica que mejor conviene a la obra poética de Rafael Ballesteros ${ }^{4}$, arrojado funambulista que sabe mantener la palabra poética (sin soslayar el componente lúdico) en delicado equilibrio entre lo discursivo (y comprensible) y el misterio ${ }^{5}$. Sabe además huir con la misma presteza de la lengua común y la palabra trillada, de las obviedades conceptuales y el lirismo convencional, que de la absoluta oscuridad (de su obra podría decirse lo mismo que de la de Góngora, que hay que estudiarla, no leerla). Precisamente la poeta Rosa Romojaro (asimismo cercana al esteticismo neobarroco) interpretaba en clave gongorina el título de Turpa (volumen publicado en 1972 y uno de los poemarios más significativos de Ballesteros) en sus estudios sobre la poesía ballesteriana (Romojaro, 1987 y 2004).

1 Probablemente José María Balcells sea uno de los críticos que más páginas ha dedicado a la obra poética de Rafael Ballesteros. Entre ellas, cabe destacar la "Introducción a la poesía de Rafael Ballesteros", texto que servía de pórtico a su edición de la obra poética de Ballesteros publicada entre 1969 y 1989 (Balcells, 1995 y Ballesteros, 1995).

2 Con esta afirmación, Balcells discrepaba de la poética ballesteriana del desvelamiento del misterio sugerida por Juan José Lanz en "La poesía de Rafael Ballesteros (1990-2010)", estudio introductorio al volumen que recogía las dos décadas siguientes de la producción del poeta malagueño (Lanz, 2015 y Ballesteros, 2015).

3 Asimismo, el poeta Francisco Ruiz Noguera (también malagueño, aunque de una generación posterior) comparte con Rafael Ballesteros una de las características más citadas y celebradas de su obra: el gusto por el neobarroco de estirpe gongorina.

4 Además de poeta, Rafael Ballesteros es también autor de las novelas La imparcialidad del viento, (2003); Huerto místico (2005), Amor de mar (2005, Premio Rincón de la Victoria de Novela Corta); Cuentos americanos, (2006); Los últimos días de Thomas de Quincey (2006, finalista del Premio Andalucía de la Crítica); y La muerte tiene la cara azul (2009, Premio Andalucía de la Crítica 2010). Un clarificador estudio de la narrativa ballesteriana puede verse en Moreno Ayora (2010).

5 La controversia sobre el difícil equilibrio entre claridad y oscuridad que debe estar presente en toda obra creativa ha terminado por convertirse en un tópico más del arte contemporáneo. En este sentido, el heterodoxo pintor afroamericano Jean-Michel Basquiat afirmaba en una entrevista de 1985: "Yo quiero ser claro, pero también quiero tener mi parte de misterio" (Dunlop y Naime, 2017). 
El conjunto de la obra poética de Rafael Ballesteros está recogido (casi íntegramente) en dos volúmenes recopilatorios publicados con veinte años de diferencia, Poesía 19691989 (Ballesteros, 1995) y Poesía 1990-2010 (Ballesteros, 2015). El primero, que vio la luz en la cuidada colección malagueña "Ciudad del Paraíso" cuando se cumplían veinte años de su trayectoria poética, reúne aquellos títulos publicados a partir de 1969: Las contracifras (1969), Turpa (1972), Jacinto. (Primera versión de la primera parte) (1983), La cava (1984), Séptimas de Amman (1985), Numeraria (1986), el cuaderno De Crísides a Jacinto (Epístola) (1987), y el poema El pie (1988), que luego pasará a formar parte de Testamenta, publicado ya en 1992. Por tanto, quedan fuera de esta primera recopilación los poemarios publicados por Ballesteros antes de 1969 (y que constituyen su "prehistoria poética"): Poemas para nuestro hijo (1965), Desde dentro y desde fuera (1966) y Esta mano que alargo (1967).

El segundo volumen recopilatorio, Poesía 1990-2010, recoge, tal y como indica su título, la tercera y cuarta década de la producción de Ballesteros, e incluye seis poemarios: Testamenta (1992), De los poderosos (1996), las dos series de Fernando de Rojas acostado sobre su propia mano (1999 y 2002), Los dominios de la emoción (2003), y, el prácticamente inédito, Nadando por el fuego ${ }^{6}$; excluye, sin embargo (al igual que ocurriera en el volumen anterior, que también excluía los textos publicados antes de 1969), tres poemarios: las partes II, III y IV del largo poema Jacinto (publicadas entre 1997 y 2002, y continuadoras de la parte I, que data de 1983). Este poema, Jacinto, singular en el panorama de la poesía española contemporánea y quizás la más ambiciosa de las propuestas estéticas ballesterianas, queda fuera de este acercamiento crítico, porque, completo, tiene entidad propia. ${ }^{7}$

1969 es, por tanto, un año clave en la trayectoria poética de Rafael Ballesteros (y clave también en la historia de la poesía española contemporánea, ya que está a punto de hacer su entrada en la arena pública una generación de poetas llamada a remover las ya estancadas aguas de la poesía social: la de los poetas novísimos). En este año, Ballesteros va a publicar el que será si no el primero de sus libros, sí el que va a dejar claro y sin lugar a dudas el enorme potencial de su personalísima voz, Las contracifras, veintiocho novedosos sonetos en los que está, quintaesenciado, todo el Ballesteros posterior: la personal asunción de las conquistas del postismo y las neovanguardias (esencialmente focalizada en el uso expresivo de los juegos de palabras y los neologismos), una vuelta de tuerca a las aportaciones de Blas de Otero al ritmo del soneto (con abruptas rupturas de los versos y el discurso), y un cierto regusto surrealista que no está reñido con el acercamiento a un neorromanticismo de nuevo cuño (características, por cierto, citadas por Balcells como claves en la poética ballesteriana) (Balcells, 2016). A ellas habría que añadir la superación de la inercia de la poesía social, todavía presente en la España de la época (sin que por ello el poeta abandone el

6 De Nadando por el fuego solo se había hecho en París una edición bilingüe no venal de veinte ejemplares (2012). Podemos encontrar un atinado análisis del conjunto de este segundo volumen en "Rafael Ballesteros, tiempo, indagación y lenguaje" (Moreno Ayora, 2015).

7 La primera parte de Jacinto se había publicado en 1983. La serie tendría su continuación tres lustros después y necesitaría casi veinte años para completarse: Jacinto. (Primera versión de la II parte) (1997), Jacinto. (Primera versión de la III parte) (1998), y Jacinto. (Primera versión de la IV y última parte) (2002). Especialmente interesante resulta también la reseña dedicada a esta última parte (Moreno Ayora, 2002). 
sentido de la solidaridad) y la estrecha comunión con esa nueva poesía que está a punto de hacer estallar las costuras de la poesía española: la poética de los 70 o poética novísima. Precisamente ese mismo año uno de los sonetos de Las contracifras aparecería en una antología de poesía joven publicada por la renacida revista Litoral de la mano de José María Amado (Amado, 1969). Aunque muchos de los poemas seleccionados todavía están en deuda con la poesía social (y ese era el objetivo último de la muestra, mostrar la disidencia política y social de los más jóvenes), también tiene aquí cabida significativamente (como adelanto de lo que está por venir) el hermosísimo poema, "Dido y Eneas", de Pere Gimferrer, el novísimo por excelencia (una clara señal de que la ciudad de Málaga, y sus jóvenes poetas, estaban al tanto de las últimas novedades literarias) ${ }^{8}$. Los dos sonetos de Ballesteros seleccionados, "Es un orgullo" y "Biopoema", 9 no son precisamente los más representativos de su ruptura con la poesía precedente (quizás primara más en su selección el que el primero hablara de la ciudad de Málaga, con un espléndido final; y el segundo, a pesar del título, de la realidad de España, lo que lo acercaba a la poesía social), sin embargo ambos textos dan ya destellos de la singularidad de los recursos empleados por el poeta y, consecuentemente, de su personal voz (véase si no su capacidad para manipular el lenguaje a través de los juegos de paranomasia y, de paso, trascender el endecasílabo y el soneto clásico).

Un libro este, Las contracifras, que además seguirá vigente a través de las siguientes generaciones de poetas malagueños que han cultivado el soneto (caso de Fernando Merlo, por ejemplo). Por estas razones, y sobre todo por su valor intrínseco (y su carácter de antesala a la poética de los 70), merecería una nueva edición, cuidada y exenta ${ }^{10}$.

Como paradigma de la personal poética ballesteriana presente en este poemario puede servirnos el soneto número 17 (subtitulado "Yo también tuve visita"), un texto metapoético excepcional que constituye no solo "uno de los más bellos momentos poéticos en la poesía de Rafael Ballesteros" (Balcells, 1995: 21), sino también uno de los ejemplos más nítidos de la fusión entre poética explícita y poética implícita que podemos encontrar en la historia de la literatura española contemporánea:

\section{Yo también tuve visita}

Vino el arcángel con la mano puesta, puso el pie de puntillas fuertemente, dobló el aire, compuso su cabello, dejó el laúd, la esquirla y con la mano

propuso una palabra. Yo miraba tiernamente unos papeles. Tenía todo, una flor y en cada mueble daba la luz. El pajarillo, entre madera

8 En las distintas colecciones del editor malagueño Ángel Caffarena publicaron en los años 70 muchos de los poetas jóvenes del momento: Gimferrer, Carnero, Siles...

9 El primero sí pertenecía a Las contracifras, el segundo era inédito en libro.

10 Un completo estudio de este poemario se encuentra en Balcells (1991). 


\section{y hierro, daba fruto. Abrió el carmín y abrió la nieve y brilló su palabra en la pared del cuarto. Daba aquello}

alegría. Levanteme. En la cintura del santo abrí la mano, Y lo conduje al quicio y con un soplo dile aire entre las alas (Ballesteros, 1995: 111).

El poema (que, en esencia, reflexiona sobre el proceso creativo) describe el momento en que el poeta (al que podemos identificar con ese yo poético que nos habla desde el texto) recibe la visita "inspiradora" de un arcángel, figura religiosa muy unida a la tradición popular y artística andaluza (y profusamente utilizada tanto en poesía como en pintura, recuérdese el emblemático dibujo de Miguel del Moral, "Ángel del sur", que ilustraba el primer número de la revista cordobesa Cántico) ${ }^{11}$, y que aquí es convocada como ambiguo sustituto de las clásicas, y paganas, musas. Pero si las musas "dictaban" las palabras de forma repentina al oído del poeta (al modo de las ilustraciones románticas), el arcángel, "de puntillas fuertemente", primero va a dejar a un lado el laúd (el aderezo de la música) y luego va a proponer una palabra "con la mano", expresiva metáfora del trabajo, casi físico, que debe realizar el poeta ante el papel en blanco: doblegar las palabras y, como un orfebre, dotarlas de una nueva forma y un nuevo significado. La irrupción del arcángel ha hecho que, si hasta ese momento el poeta se encontraba en un entorno amable y conocido ("tenía / todo, una flor y en cada mueble daba / la luz"), y escribía oyendo el canto de un humilde pajarillo, hermano menor del ángel y preso "entre madera y hierro" (expresiva metáfora de los catorce barrotes de la cárcel del soneto), ahora, la palabra traída por un arcángel en libertad romperá las convenciones y llenará de luz y alegría todo el cuarto: el milagro de la creación poética en libertad ha tenido lugar. El poeta da las gracias y sopla "entre las alas" para que el arcángel de la inspiración prosiga su camino.

Esta explícita reflexión metapoética (muy en línea con una de las vertientes temáticas más citadas por la crítica acerca de la poesía de los 70, y que propone y defiende la más heterodoxa libertad creadora) ${ }^{12}$ tiene además su correspondencia, como ya se ha apuntado, con la poética que está implícita en la propia escritura del texto. El poeta ha elegido una estrofa clásica, el soneto, y ha construido también unos perfectos endecasílabos (tal y como corresponde a un paisaje conocido), pero al mismo tiempo ha tenido el cuidado de ir quebrando el ritmo versal y estrófico del poema con abruptos encabalgamientos, para, por último, romper abiertamente la convencionalidad del soneto (igual que antes el arcángel

11 La figura del ángel (o arcángel) tiene una larga trayectoria en la cultura popular andaluza, "tener ángel” se utiliza con frecuencia en la Andalucía occidental como sinónimo de "tener duende", un término muy utilizado por Lorca para explicar la poesía (o el cante) en "estado de gracia”. Su revés negativo, "el mal ángel”, ha dado lugar al "malaje".

12 Aunque la práctica metapoética no es algo nuevo en la historia de la poesía, sí es nuevo el hecho de que se convirtiera, de manera casi obsesiva, en el tema más frecuentado por la mayoría de los poetas de los 70, probablemente porque a su través era posible cuestionar el propio funcionamiento del lenguaje. 
"había roto" la paz doméstica que reinaba en la casa del poeta) con el añadido de un último verso pentasílabo (a modo de coda final) y que sirve (tras el "quicio" del verso catorceavo) para liberar la imagen de esas alas angélicas que a partir de ahora volarán sobre lo ya conocido y previsible: "con un soplo dile aire / entre las alas."

Sin embargo, y a pesar de que el lector pueda seguir sin dificultad las distintas secuencias (casi cinematográficas) que se suceden en el poema, el poeta ha sabido sostener el delicado equilibrio entre claridad y misterio que caracteriza su elaborada poética con la inclusión de brevísimas y acertadas imágenes de impronta surrealista ("dobló el aire", "abrió el carmín y abrió la nieve", "en la cintura del santo abrí la mano"). Un procedimiento que pronto se convertirá en una de las señas de identidad más reconocibles de la escritura poética ballesteriana y que de manera tan clara se manifiesta en la metáfora de la libertad creadora encarnada por la angélica visita: la poética explícita y la poética implícita de Ballesteros quedan así fundidas en el mismo texto.

Desde 1969 hasta la década de los 90, Ballesteros va a publicar títulos de poéticas tan diversas, en apariencia, como Turpa, Séptimas de Ammán o la primera parte del extenso poema Jacinto, (la gran obra del poeta, según parte de la crítica, y que, por tanto, merece un estudio exento). Y con ello la poesía de Rafael Ballesteros va a ir configurándose como una de las más personales de su generación: la que sirve de puente entre dos maneras opuestas de entender la práctica poética, la poesía social de los 50 y la novísima ${ }^{13}$. Aunque muchas veces se ha defendido, desde el mismo prólogo de Castellet, la ruptura entre estas dos formas de concebir la poesía, la realidad es mucho más compleja (baste recordar el enorme legado del grupo cordobés de Cántico, reivindicado luego desde el mismo centro de los novísimos; la pervivencia más o menos subterránea de las vanguardias, a través, sobre todo, del neosurrealismo y el postismo; o la evolución de la poesía social a una poesía más personal representada por Gil de Biedma). Puede afirmarse, por tanto, que la poesía de Rafael Ballesteros se caracteriza por amalgamar (y personalizar) en cada uno de sus poemarios las poéticas nacidas de todas estas fuentes.

Por un lado, el componente ético propio de los 50 sigue vigente, aunque de forma heterodoxa, en un texto como "Sobre todo el alba" (segunda parte del poemario La cava, 1984), dedicado a la figura del incómodo poeta malagueño José María Hinojosa, que fue fusilado en agosto de 1936 por milicianos izquierdistas que actuaban por cuenta propia (apenas unos días después de que Federico García Lorca fuera detenido y asesinado por el otro bando ${ }^{14}$. Con esta dedicatoria, Ballesteros rendía de forma valiente y honesta un doble homenaje (ético y poético) al poeta malagueño: al hombre muerto por sus ideas (fueren las que fueren, sin hacer distingos ideológicos o partidistas), pero también, con toda seguridad, al poeta vanguardista, al Hinojosa autor de La flor de Californía, un libro que puede considerarse como el primer poemario plenamente surrealista de la literatura española (fue publicado en 1928,

13 El poeta Gabino Alejandro Carriedo también podía escribir de forma simultánea poesía social y otra "postista", tal y como puede seguirse en sus obras completas, Poesía, editada en 2006 por la Fundación Jorge Guillén.

14 José María Hinojosa (Campillos, Málaga, 1904 - Málaga, 1936) fue fusilado junto a Luis Altolaguirre (hermano de Manuel) y cuarenta y seis detenidos más en la tapia del Cementerio de San Rafael de Málaga el 22 de agosto de 1936. 
mucho antes de que Lorca escribiera su Poeta en Nueva York o de que Cernuda se acercara al surrealismo en los primeros años 30). En el texto (cuyo título, "Sobre todo el alba", hace alusión a la hora en que solían hacerse los fusilamientos, al amanecer y sobre las tapias de los cementerios) Ballesteros va a utilizar uno de sus procedimientos más queridos (y de alguna manera heterodoxamente dramático): la polifonía de voces. "La voz", "El asesinado", "El que mata", "El campesino" y "El poeta" van alternando sus voces a lo largo del poema en un juego poético que acaba por resultar ambiguo. ¿”El asesinado" no es "El poeta"? ¿O "El poeta" es el alter ego del escritor que escribe el poema? Ambigüedad y misterio que nunca acaba de ser desvelado. "La voz" narra sutilmente lo acontecido mientras reflexiona sobre el silencio y el olvido, destino último del poeta asesinado, pero también quizás de todos los muertos:

\author{
Pasó ululando la luna, \\ sopesando el entorno. $Y$ \\ rozó con su materia el \\ recinto, la tapia, los \\ olvidos. Pasó. Dejó su \\ cortinaje. \\ El silencio primero. \\ Mas después fue la \\ brisa. Las alzadas \\ proezas del sol y de los \\ astros. El silencio. La \\ vida. \\ Pasó la luna y \\ la vida con ella. Y por \\ entrambas de ellas, los \\ doseles del mundo. \\ La pausa. Los olvidos. (Ballesteros, 1995: 213)
}

La reivindicación de José María Hinojosa, el hombre y el poeta, que Ballesteros construye a partir de la quiebra del silencio y el olvido impuestos, amplía y enriquece las tesis sostenidas por la poesía social al alinearse implícitamente con tantos otros conocidos textos dedicados a poetas muertos o desaparecidos (de Federico García Lorca a Miguel Hernández).

Sin embargo, el poeta malagueño sabe alejarse de la denuncia panfletaria (que tan flaco servicio prestó a la poesía del medio siglo) gracias, sobre todo, a la sutileza de las ideas y a la sensorialidad de las imágenes. Ahora la voz de "El asesinado" deja oír su lamento:

Es de jazmín la última

luz. Y el fuego que avecina

su escarcha.

Solo frío en

el azul intenso. (Ballesteros, 1995: 208) 
Esta misma memoria sensorial (el frío como imagen física del desvalimiento del individuo ante la irracionalidad del odio) va a ser utilizada más tarde por Ballesteros (en uno de sus libros más personales, Los dominios de la emoción, publicado en 2003) para levantar en el poema "Sinfonía en tres tiempos. Opus LXXIV" el recuerdo de su detención y encarcelamiento en Barcelona por motivos políticos en diciembre de 1974. El texto, que recorre (a la manera mística) las tres etapas del proceso (presencia ante el juez, breve estancia y puesta en libertad), y que supone una nueva mirada a la realidad social y política del mundo contemporáneo, se vale de la ironía para mitigar la injusticia del dolor causado:

En este reino solo se entra desnudo. Yo

mostré sólo mi culo. Político. Político. Uf, pronto,

pronto el hatillo. Y entré.

Qué frío. Frío. Pero eso sí. Eso es verdad:

Era mejor que el de la muerte (Ballesteros, 2015: 279).

Esta "sinfonía" puede leerse por tanto como una actualización de la poesía social hecha a posteriori desde la ironía y el recuerdo. La permanencia y actualidad de lo recordado (ocurrido treinta años antes) se hace patente en los breves retazos de conversación de la visita familiar a la cárcel en la que está detenido el poeta y que aparecen transcritos en estilo directo para que no pierdan efectividad:

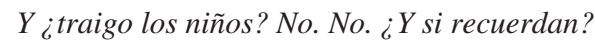

¿Y si les queda, ahí, en la mirada, así para siempre

las rejas? Y tú dijiste: quizá, quizá fuera mejor para

que no olvidaran (Ballesteros, 2015: 281-282).

Los versos finales resultan de meridiana claridad; el recuerdo y la memoria harán trascender la historia y sus posibles consecuencias gracias a la escritura del poema.

No es Ballesteros el único poeta que regresa al pasado para recuperar ese componente ético-reflexivo tan necesario en la nueva sociedad nacida de los rescoldos de aquella que fue; también la poesía de otro poeta cercano, Antonio Jiménez Millán (fundamentalmente en su poemario Clandestinidad), recurre a la mirada individual (la propia experiencia) y a la memoria (personal e histórica) para ampliar sus intereses y convertirse en reflexión actualizada (e irónica denuncia) acerca de nuestra identidad (personal, claro, pero también cultural, social y política):

He guardado la llave del desván

que esconde un manifiesto

con cubierta roja,

los pasquines,

la prensa clandestina (Jiménez Millán, 2011).

Ballesteros va a dar continuidad a estas reflexiones ético-filosóficas en dos libros que resultan fundamentales para comprender la enorme complejidad de su poética: De los poderosos y las dos versiones de Fernando de Rojas acostado sobre su propia mano. Dos 
poemarios en los que el poeta además de ensayar el poema en prosa recupera la tradición clásica de los consejos a los más jóvenes. Una temática que tiene su precedente en la epístola De Crísides a Jacinto, libro anterior donde el poeta se desdoblaba en los dos personajes del título: el anciano filósofo Crísides y el joven Jacinto (que a su vez es también el protagonista del extenso poema del mismo nombre). En la epístola última de De los poderosos Ballesteros acude de nuevo a la reflexión metapoética para confesar que todavía tiene fe en el poder de la palabra, acercándose con ello a la poesía concebida como instrumento para cambiar el mundo:

Y como sé, Jacinto, que los jóvenes creéis que cada acto contiene en sí su propia evidencia, y cada evidencia, por sí misma, sus expresiones precisas y ajustadas, debes saber que aún hoy, tu amigo Crísides, ya viejo, a pesar de vivir en estos tiempos tan desabridos y terribles y llevar dentro del corazón experiencias muy dolorosas, pone toda pasión y cuido en epístolas y versos porque sigue creyendo que la palabra puede cambiar no solo un corazón sino también el mar (Ballesteros, 2015: 226).

El propio carácter del libro, fundamentalmente ético-filosófico, y el estar dirigido a jóvenes receptores, obliga al poeta a perder hermetismo y ganar, por tanto, en claridad expresiva; sin embargo, Ballesteros, que no quiere renunciar a la riqueza lingüística consustancial a su personalísima poética, con muy buen tino y siendo fiel a su trayectoria, utiliza con frecuencia un lenguaje conscientemente arcaico y lleno de connotaciones:

Lo que hagas: hazlo sencillo y común y vive despacio y atento. Aún entre los nublos más oscuros de las callejas más solitarias puede encenderse repentinamente la luz de una alcuza (Ballesteros, 2015: 219).

De otro lado, en Fernando de Rojas acostado sobre su propia mano (en sus dos ediciones, 1999 y 2002) Ballesteros recoge una tradición más directa y popular, la de las sentencias, máximas o aforismos (tan andaluzamente clásicas). Eso sí, de manera heterodoxa y dándole la vuelta al tópico: "Quien tiene un amigo lleva la gloria de la mano. El que sabe estar solo está sentado sobre ella" (Ballesteros, 2015: 232).

Esta misma poética, aunque cruzada con el espíritu lúdico de las greguerías, tiene su correspondencia con parte de la obra de otro poeta malagueño de su misma generación, Rafael Pérez Estrada (fundamentalmente, sus conocidas rafaelerías): "Hay espejos tan tímidos que se rompen ante el esplendor de un desnudo perfecto" (Pérez Estrada, 1988).

Ambos poetas, Ballesteros y Pérez Estrada, comparten además el hecho de haberse convertido en referencias neovanguardistas de la poesía malagueña de finales del siglo Xx. Si repasamos la nómina de poetas sociales (en cualquiera de sus muchas antologías) puede constatarse que la presencia de autores andaluces resulta muy escasa. Durante los años cuarenta y cincuenta, la mejor poesía escrita en Andalucía ha sido la publicada por el grupo cordobés de la revista Cántico (en un momento político y cultural, además, muy poco propicio para una estilística tan depurada). A partir de los años 60 comienza una tímida reacción frente a la dominante poesía social y surgen nombres (como Antonio Carvajal o 
Alfonso Canales ${ }^{15}$ ) que ponen toda su atención en recuperar la riqueza del lenguaje poético; sin embargo, una parte de la joven poesía malagueña va a encontrar (y desarrollar) esa riqueza en la senda neovanguardista (sea neosurrealista o más cercana al postismo). Miguel Romero Esteo, Rafael Pérez Estrada y Rafael Ballesteros, cada uno de ellos con personalidad propia y obra en marcha, van a ser ahora los abanderados de una cierta resurrección de las vanguardias (que no está reñida con la contestación política) y que va a consistir sobre todo en mantener viva la llama de la experimentación poética y de la creación en libertad ${ }^{16}$, lejos ya de encorsetamientos ideológicos o culturales.

Asimismo, la tradición de aforismos y sentencias seguirá también presente en la obra de poetas más jóvenes, como José Antonio Padilla ${ }^{17}$ (1975-2009), autor del poemario Colección de olas, un conjunto de aforismos (o greguerías o mínimos poemas, que de todo ello participa) que resultan deudores tanto de las vanguardias clásicas y las neovanguardias malagueñas, como del gusto por la sentencia de la Andalucía más honda (tan cercana al senequismo): "Vivimos en el extrarradio de nosotros mismos" (Padilla, 2004).

Incluso la poesía más reciente gusta de incorporar dentro del poema versos que funcionan como una sentencia. Es el caso del joven Alejandro Simón Partal ${ }^{18}$, cuya obra poética aparece salpicada de reflexiones cercanas al aforismo: "Vivir resbalando es una forma / de evitar la caída" (Simón Partal, 2012).

Y es que el aforismo tiene también otra misión: la de ser reflejo/espejo de las vivencias e ideología del poeta. Rafael Ballesteros deja clara sus creencias en esta reflexión de argumento difícilmente refutable: “¿Qué eres antes de nacer? Entonces, ¿qué vas a ser después de la muerte?” (Ballesteros, 2015: 240).

De otro lado, y tal como hemos ido adelantando, el neovanguardismo (y por ende la riqueza léxica de la nueva poesía) recorre prácticamente toda la obra de Ballesteros (incluso en los temas menos proclives) y así lo han señalado la mayor parte de los críticos que se han ocupado de ella (Balcells, 1995 y 2016, y Lanz, 2015). En muchas ocasiones esta riqueza léxica se despliega en íntima conexión con el uso de recursos de impronta neobarroca (Romojaro, 1987), así ocurre en el heterodoxo poemario Turpa, que aunque quizás sea uno de sus textos más complejos, el lector siempre puede seguir el hilo conductor que lo sustenta a partir de los títulos y subtítulos de los poemas; como en esta "Presentación del labio", que viene precedida por una breve síntesis argumental: "Sabido que es por Turpa el enorme maleficio del labio, lo acorrala y persigue". Las imágenes tradicionales del barroco clásico referidas a labios y dientes ("perla", "clavel" o "rubí") o las irracionalistas, más

15 A estos nombres podría añadirse el de María Victoria Atencia, que comenzaba a publicar en los primeros 60 , pero no será hasta los 70 y 80 cuando su obra fundamental comience a ser reconocida.

16 Pienso en nombres como José Infante, Fernando Merlo, Javier Espinosa o Juan Ceyles, que tienen en común su enorme capacidad creadora.

17 José Antonio Padilla (Álora, 1975-2009) murió prematuramente. Dejó publicados dos poemarios, Colección de olas (2004) y Noches áticas (2006).

18 Alejandro Simón Partal (Estepona, 1983) ha publicado hasta el momento cuatro libros de poemas: El guiño de la chatarra (2010), Nódulo noir (2012), Himnos abdominales (2015), y La fuerza viva (2017). 
cercanas a las vanguardias ("Oh dolor / de la esquina entre las líneas"), se alternan con una orientación léxica de reminiscencias neobarrocas (“carmín”, "libar”):

\author{
Si la perla destila el contenido \\ el carmín restituye el colorido. \\ Oh ciencia \\ del albarde y de la pinza \\ que plantean, al libar, los dos sentidos. \\ Cuando el clavel no rompe la armonía \\ el cúmulo de perlas sí se entrega. \\ Oh labios \\ con los dientes confundidos. \\ Si es el rubí que canta y que destruye, \\ por cada perla surgen veinte fuegos. \\ Oh dolor \\ de la esquina entre las líneas. (Ballesteros, 1995)
}

Todos estos recursos, aunados al viaje de vuelta del nosotros al yo (y su incursión, por tanto, en el neorromanticismo) quedan luego multiplicados en una polifonía de voces que amplifica el discurso poético y lo acerca a la literatura dramática o incluso al Auto Sacramental (y de alguna manera también a muchos de los presupuestos propios de la poesía de los 80). Así ocurre no solamente en algunos poemas de La Cava (como ya hemos visto), o en las cuatro partes de Jacinto (donde se suceden múltiples voces, "La Ella: la Muerte", "Jacinto", "El Mentor", "La Sabia: La María", "El Arcángel: La Flor", "SatánBelcebú" o los distintos "Coros"), sino también en "Antecedenta" (poema doble que sirve de introducción a otro poemario fundamental en la trayectoria poética de Ballesteros, Testamenta), en el que se alternan las voces de "El que alienta" y "El que está al otro lado".

Y precisamente en este libro puede seguirse perfectamente el viaje/trayecto (que es a la vez asunción personal de poéticas distintas) seguido por Ballesteros a lo largo de su obra. Testamenta es un poemario de estructura singular y el primero de los títulos recogidos en el segundo volumen recopilatorio, Poesía (1990-2010), y también, en realidad, un único y largo poema en el que Ballesteros recrea y convoca a diferentes figuras cercanas o familiares (del presente y del pasado) con el pretexto de convertirlos en beneficiarios o testigos de su testamento de vida (así muchos de los poemas comenzarán con "Nombro heredero..."; en tanto que otros llevarán el título de "Testigos"). Este procedimiento sirve al poeta para rendir homenaje a todo su entorno familiar y doméstico (y de paso levantar ante el lector el recuerdo de aquello que fue), pero también, y eso es lo más decisivo, para ir construyendo a lo largo de todo el libro los diferentes rostros del personaje que nos habla desde el propio texto, alter ego de sí mismo (el nombre de "Rafael" queda transformado en "Ael", protagonista del texto y testamentario). El poeta puede esconderse así tras el distanciamiento que proporciona el uso de la tercera persona (aunque eso no ensombrezca su estirpe neorromántica): 
Ael miraba al mar: las cenizas

candentes: los tules y hervideros

de aquella juventud, los aires caldeados

y extensos de los niños. ¡Aquel

pelo radiante! ¡Aquella azulatría! (Ballesteros, 2015: 114).

A este personal neorromanticismo se unen, como ha terminado por ser habitual en la obra ballesteriana, procedimientos que son más propios de la heterodoxa creatividad neovanguardista: desde el feliz hallazgo de luminosos y certeros neologismos ("dudivoso" o "donceliello"), a la construcción de imágenes de estirpe picassiana, a veces sabiamente fundidos en una misma palabra: “¡Aquella azulatría!”"19

Testamenta, por tanto, reivindica el papel de nexo entre la vieja y la nueva poesía jugado por el poeta, porque si Jaime Gil de Biedma, al superar la poesía social y dar entrada al yo múltiple, adelantaba la poesía de la experiencia y se convertía en el poeta más citado a lo largo de los ochenta, la poética creadora de Ballesteros (que cuestiona desde muy pronto la esencia misma del lenguaje) va a servir también de nexo ininterrumpido entre las poéticas de los 70 y la corriente neovanguardista de los ochenta y noventa. ${ }^{20}$

A pesar de las enormes diferencias entre ambas poéticas, Gil de Biedma y Rafael Ballesteros utilizan con frecuencia mimbres muy similares: ambos recurren a tópicos tan clásicos como la añoranza de la juventud, el paso del tiempo o la inevitabilidad de la muerte; también ambos juegan a desdoblar (y multiplicar) los distintos yoes que nos componen o suceden, e, igualmente, no es extraño encontrar a lo largo de sus trayectorias poéticas momentos en que se duelen de los eternos males de la patria y de su situación en la historia ya que ambos "vienen" de la poesía social. Donde Gil de Biedma ironizaba: "En un viejo país ineficiente, / algo así como España entre dos guerras / civiles" (Gil de Biedma, 1975), Ballesteros se pregunta: "qué hace, qué / hace un cándido como tú, en una patria / sin ley como ésta." (Ballesteros, 2015: 312). Aunque el resultado final de sus propuestas estéticas responda a intereses y poéticas muy dispares.

Esta forma de construir la figura del "yo" a partir de la de los "otros", camina en paralelo a la importancia dada a la práctica metapoética, probablemente la característica que mejor define la indagación existencial en la escritura poética, pero también la que mejor singulariza la escritura ballesteriana. ${ }^{21}$ El resultado final, sin embargo, queda casi siempre sutilmente velado por la tensión a que el poeta somete al lenguaje y el uso (muchas veces concentrado, a la manera gongorina) de recursos clásicos, como en esta hermosa (y transparente) reflexión metapoética (en la que los términos "lecho" y "pluma" quedan metafóricamente identificados como continente y origen de muchas posibles personalidades y emocio-

19 El poema en su conjunto (y sobre todo esa "azulatría") parece poner texto no solo al período azul picassiano, sino especialmente a la desbordante alegría que impera en el pequeño lienzo "Dos mujeres corriendo en la playa" (1922) que se conserva en el Musée Picasso de París.

20 En 1983, la corriente neovanguardista dejará su impronta con el éxito del poemario surrealista De una niña de provincias que se vino a vivir en un Chagall, de la entonces jovencísima Blanca Andreu.

${ }_{21}$ Como ejemplo del extendido uso de la práctica metapoética en la poesía más actual puede verse Linterna, el último, y brillante, poemario de Juan Manuel Villalba (Villalba, 2017). 
nes) construida a partir de antítesis, paradojas y neologismos, lo que no es sino una manera implícita de explicar/definir la práctica metapoética desde la propia escritura del texto, quizás (como hemos ido viendo) la aportación más personal de la escritura ballesteriana al conjunto de la poesía española contemporánea:

\author{
Igual que el lecho, es la pluma \\ ámbito diverso y amplio donde \\ junto al amor, cabe el desamparo \\ y la aflicción. \\ Allí se extiende \\ la desazón y la alegría: igual al \\ romo que llora la gacela, que al \\ tembloroso y solo que gime empezonado, \\ que lo mismo al galán que al viejo \\ desprovisto: pluma diversa, siempre la \\ misma: continua en sí, punta y cabida (Ballesteros, 2015: 171).
}

Esta pluma diversa, siempre la misma (antítesis resuelta en paradoja que nos remite también al campo de plumas gongorino) es probablemente la mejor definición hecha hasta ahora de la riqueza y diversidad de la poética ballesteriana y complementa además la personal heterodoxia que antes había simbolizado la visita del arcángel. Una manera de concebir la práctica poética que al fin y al cabo no es sino la búsqueda del más delicado equilibrio entre claridad discursiva y tensión sintáctica; entre el uso de un vocabulario certero y natural, y la atinada creación de expresivos neologismos (nótese, por ejemplo, la similitud fónica, y al mismo tiempo el contraste semántico/expresivo, entre el creativo, y sensual, "empezonado" y el reiterativo y prosaico "empecinado", también la enorme distancia poética que va entre "gemir empecinado" y "gemir empezonado").

Ballesteros vuelve de nuevo a reflexionar sobre el impulso poético que protagonizaba su más conocido texto de tema metapoético, "Yo también tuve visita", en un poema fundamental para adentrase en su obra, "Exilio", de Los dominios de la emoción (2003). Aquí el poeta utiliza la metáfora de la manzana (tan llena de connotaciones) para dejarnos algunas claves de las bases de su poética. En él aparecen tres de los pilares que la sostienen, Fernando (de Rojas), Rubén (Darío), y Carriedo (Gabino Alejandro), tres momentos de la historia de la literatura que representan a su vez tres conceptos distintos (y complementarios) de la escritura poética:

Tengo una manzana de piel fina

y tersa — pondal-que guarda temblor

y ansia. Esas que Fernando las tomaba

en el jardín y le decía toma tú también,

Melibea, mientras esperas del amor.

Otra tengo también que es sólo nada, como una bola tosca y gaseosa, que llevan en cerón los labriegos, mula allí, mula acá, pregonando por entre los valles y oliveras. 
Esas que a las mozas Rubén daba para ofrecerles el amor.

$Y$ otra también, plena, rotunda pero vanal, verde y juga, una parte placer, la otra, un vacío infinito. Son ésas que

Carriedo comía, siempre dejando la mitad, así que amaba su amor. (Ballesteros, 2015: 305)

El deseo y la palabra (más allá del amor), se identifican con tres tipos de manzana, "están allí las tres, sobre el frutero / azul de Talavera, en el salón de los / pecados", pero ninguna de ellas es capaz de explicar el sentido último de la existencia. Esta insobornable certeza, finalmente, "nos condena a nuestro exilio" (Ballesteros, 2015: 305-306).

Un exilio que tiene su correspondencia con el destierro que supone la muerte, otro de los temas más frecuentados por el poeta a lo largo de toda su obra. En el poema "Al término" (también de Los dominios de la emoción), el poeta expresa sin dramatismo sus últimas voluntades:

Dejadme un espacio pequeño donde pueda
poner mi cuerpo, yo, y ése otro que incesante
me acompaña. Sí, dentro de la casa, si así lo
decidís, en la habitación de arriba, donde hablar solo
sea posible, y sonreír, llorar así, suave, suave, y que
si os pregunto por mí y por ella, vosotros
comprendáis. Y que podáis decirme, si queréis,
se fue, se fue, y sabemos que nunca volverá,
ya nunca volverá (Ballesteros, 2015: 319).

La vida como acabamiento va a tener su mayor desarrollo en uno de sus últimos poemarios, el prácticamente inédito Nadando por el fuego (del que solo se había hecho en París una edición bilingüe francés-español de veinte ejemplares en 2012). El texto está compuesto por un conjunto de reflexiones hechas desde la atalaya de los años en las que se dan la mano cierto escepticismo existencial con la aceptación del paso del tiempo y la cercanía de la inhóspita vejez. Los posibles tintes melancólicos son a veces salvados por una jocosa ironía. Como en el poema "Divertimento II" (aquí resplandece el expresivo neologismo tírito, adjetivo formado a partir del verbo tiritar y cuya eficacia queda multiplicada por el vecino esdrújulo diáfano). El poeta insiste en la multiplicidad del yo y, por tanto, en las distintas miradas (y poéticas) resultantes:

$Y$ un Ballesteros hay que es único en el mundo, porque suma cuatro: solo por ser cosa viviente ya lleva en su collarino dos; más uno cuando se pone peluca de poeta y le anochece aún más su oscuridad, y cena sopa helada cuando amanece; y por quedarse mudo, lleno de asombro, diáfano y tírito como los niños ante la vida, cuatro es (Ballesteros, 2015: 365). 
Por todo ello, la obra poética de Rafael Ballesteros deja constancia de que la superación de la poesía social y el adelanto de algunas de las conquistas que triunfaron luego con los novísimos (a excepción quizás de ese halo de cosmopolitismo culturalista tan propio de los 70) hacen del conjunto de su obra un eslabón imprescindible en la poesía española del último medio siglo. Porque, tal y como afirmaba Juan José Lanz, "la poesía de Rafael Ballesteros [...] apunta a una superación de los modelos expresivos [...], en una poética en constante indagación, en continua búsqueda, que hace del lenguaje su campo de acción" (Lanz, 2015: 93).

En fin, el compromiso ético y social (implícito o explícito) presente en la obra de Ballesteros no solo trasciende las preocupaciones sociales de los 50 gracias a la imbricación de la memoria individual en la memoria social, sino que además es capaz de renovar sus formas expresivas con el uso de muchos de los recursos propios de las vanguardias más heterodoxas (desde la creación de certeros neologismos a la ruptura de la frase o las traslaciones sintácticas). A esta indagación en las posibilidades del lenguaje se une el análisis y ensanchamiento de los distintos yoes del personaje poético (y del poeta) en una forma de neorromanticismo que corre en paralelo a una de las características más citadas de la poesía de los 80; y, finalmente, (en línea con los poetas del 70) las reflexiones metapoéticas que jalonan su obra además de cuestionar el papel de la inspiración en el origen del poema, evidencian también la multiplicidad (y riqueza) de las poéticas resultantes; aunque siempre sea posible constatar que existe un eje capaz de vertebrar el conjunto de su obra: la fe inquebrantable en el poder de la palabra; de ahí el esfuerzo del poeta por domeñar y recrear el lenguaje, una tarea que deviene esencial.

Es más, las distintas maneras (temáticas o expresivas) de su quehacer poético siguen vigentes, tal y como hemos venido apuntando, en las sucesivas generaciones de poetas cercanos (caso de Rafael Pérez Estrada, Rosa Romojaro, Francisco Ruiz Noguera, José Infante, Fernando Merlo, Juan Ceyles, Antonio Jiménez Millán, Juan Manuel Villalba, José A. Padilla o Alejandro Simón Partal).

Yo nunca dudé: ;siempre mejor ahogarse que mirar! ¿Es que hay otro final mejor que ser llevado hasta tu término por el agua que fluye? ¿Que morir en la mar y desnudo? (Ballesteros, 2015: 335). 


\section{REFERENCIAS BIBLIOGRÁFICAS}

Amado, José María (ed.) (1969): Litoral, 10.

Balcells, José María (1991): "Claves de Las contracifras, de Rafael Ballesteros", Scriptura, 6-7, 215-222.

- (1995): "Introducción a la poesía de Rafael Ballesteros", en Poesía 1969-1989, Rafael Ballesteros, Málaga, Ayuntamiento de Málaga.

- (2016): "Rafael Ballesteros y los vislumbres del velo", Lectura y Signo: Revista de Literatura, 11, III-VIII.

Ballesteros, Rafael (1995): Poesía 1969-1989 (edición de José María Balcells), Málaga, Ayuntamiento de Málaga,

— (2015): Poesía 1990-2010 (edición de Juan José Lanz), Málaga, Fundación Unicaja.

Bianchi, Marina (sel.) (2014): Humanismo solidario. Poesía y compromiso en la sociedad contemporánea, Madrid, Visor.

DunLoP, Geulf y Sandy NAIME (2017): Basquiat Boom for Real, Berlín, Prestel.

GIL DE BIEDMA, Jaime (1975): Las personas del verbo. Barcelona, Seix Barral.

JimÉneZ Millán, Antonio (2011): Clandestinidad, Madrid, Visor.

LanZ, Juan José (2015): “La poesía de Rafael Ballesteros: 1990-2010”, en Poesía 1990-2010, Rafael Ballesteros, Málaga. Fundación Unicaja, 9-98.

Moreno AyORA, Antonio (2002): “Jacinto (Primera versión de IV y última parte), Rafael Ballesteros, Alfar, Sevilla, 2002”, Canente Revista Literaria, 3-4, 457-464.

- (2010): "Rafael Ballesteros, poeta y narrador", Estudios Humanísticos. Filología, 32, 183-196.

- (2015): "Rafael Ballesteros, tiempo, indagación y lenguaje", EPOS, xxxi, 533-540.

Padilla, José Antonio (2004): Colección de olas, Málaga, Puerta del Mar.

PÉrez estrada, Rafael (1988): Libro de los espejos y las sombras, Huelva. Diputación Provincial de Huelva.

Romojaro, Rosa (1987): "Una poética manierista en los años setenta: Turpa, de Rafael Ballesteros", Analecta Malacitana, 10-1, 107-130.

- (2004): "Trayectoria poética de Rafael Ballesteros", en Lo escrito y lo leído. Ensayos sobre literatura y crítica literaria, Barcelona, Anthropos, 121-134.

Ruiz Noguera, Francisco (2014): La gruta y la luz, Madrid, Visor.

Simón PARTal, Alejandro (2012): Nódulo noir, Sevilla, Renacimiento.

Villalba, Juan Manuel (2017): Linterna, Valencia, Pre-Textos. 